\title{
Impact of iron deficiency on cognitive functions and effect of iron supplement in children between 5-10 years: Indian perspective
}

\author{
Naseem A ${ }^{1}$, Khan S. A. ${ }^{2}$, Lalani $\mathbf{N}^{3}$ \\ ${ }^{1}$ Dr Altaf Naseem, Professor, ${ }^{2}$ Dr Shafi Khan Ali Khan Gari, Sr Resident, ${ }^{3}$ Dr Nizar Lalani, Dip Child Health, \\ Sr.Resident. All authors affiliated with Dept of Pediatrics, Deccan College of Medical Sciences, Kanchanbag, \\ Hyderabad, India.
}

Author for Correspondence: Dr Altaf Naseem, Professor, Dept of Pediatrics, Deccan College of Medical Sciences, Kanchanbag, Hyderabad, India. Email:docaltaf@ rediffmail.com

\begin{abstract}
Background: Data on iron deficiency anemia (IDA) and cognitive function in Indian children aged 5-10 years is limited. Objective: To study the extent of IDA, its impact on cognition and evaluate the effect of iron supplementation on cognitive function in children with IDA. Methods: Children aged 5-10 years $(n=193)$ were grouped into overt (group I $\mathrm{n}=71$,Ia- received iron supplements, Ib -without iron supplement), latent (group II, $\mathrm{n}=48$, IIa- received iron supplements, $\mathrm{IIb}$-without iron supplement)) anemia and non anemia (Group III, n=74) categories. Basic hematological investigations (HB, MCV, peripheral smear and total iron binding capacity) were done at baseline to categorize into groups. Cognitive function tests were performed at baseline and at the end of the study. Deworming with broad spectrum anthelmintic agent Albendazole(400mg stat) followed by iron supplements for 3 months was administered to Group Ia and IIa children. Results: Of 193 children, 119 (61.65\%) had Iron deficiency, seventy (36.27\%) had overt anemia and 49(25.397\%) had latent form. Mean \pm SD Haemoglobin at baseline was $11.80 \pm 1.71 \mathrm{gm} / \mathrm{dL}, \mathrm{MCV} 82.07 \pm 4.69$ femolitres, TIBC was $403.58 \pm 58.77 \mu \mathrm{g} / \mathrm{dL}$. Cognitive functions were significantly $(\mathrm{p}<0.005)$ higher in non anemic children. Iron supplements were administered for 3 months to 58 students. Treatment compliance was $96.0 \%$. Hemoglobin $>12 \mathrm{gms} / \mathrm{dL}$ was seen in $80.83 \%$ (156/193) had < 12 gms/dL, after iron supplements; Mean \pm SD Haemoglobin was 12.76 $\pm 1.39 \mathrm{gm} / \mathrm{dL}$ and that of visual recall, digit span and clerical task changed from $5.63 \pm 1.08,4.03 \pm 1.0$, and $7.16 \pm 1.4$, respectively to $6.34 \pm 0.82$, $4.35 \pm 0.78$ And $7.98 \pm 1.19$ respectively. Higher scores were seen in those with Haemoglobin> 12 gms/dL. Conclusion: Non anemic children perform better than those with anemia; performance of those with latent anemia is better than those with overt anemia. Iron supplementation helps in improved performance in these children.
\end{abstract}

Key words: Cognitive functions, Haemoglobin, Iron deficiency anemia, Iron supplements.

\section{Introduction}

Iron deficiency anemia in childhood a common, yet a clinically important reversible state of malnutrition, has well established relationship with impaired work capacity, lowered cognitive functions, impaired immune responses and growth retardation [1-2]. Cognitive functions (memory, intelligence, and sensory perception) have been related to intelligence and its afflictions can affect academic performance and thus have a greater impact on the psyche, interpersonal relationship and social life of a child [3-5]. If untreated,

Manuscript received: $19^{\text {th }}$ April 2016

Reviewed: $28^{\text {th }}$ April 2016

Author Corrected; $14^{\text {th }}$ May 2016

Accepted for Publication: $26^{\text {th }}$ May 2016 these changes may become irreversible which makes early recognition and treatment crucial. For this reason, iron supplements are being prescribed routinely in toddlers and during early childhood as a preventive measure, which has proved effective [6-7].

Iron deficiency has been linked to lower intelligence in children [8]. Lower iron levels have been associated with poor academic grades [9-10]. Iron supplements have shown to improve academic performance [11]. Hence, early recognition, treatment and reversal of perturbed cognitive functions is of utmost importance in order to improve academic performance in a country like ours where academic grades are considered as 
ultimate. Studies have shown that, of cognitive functions, the benefit of iron supplementation appears to be much more evident in the areas of attention, persistence, concentration, perception, visual motor coordination and social comprehension [12-13]

Medical fraternity has focused medical care and nutrition supplements during antenatal care [14], infants [15-18] and to children who are $<5$ years of age [1921] to improve the general growth \& development and cognitive functions with positive results but with less focus on the children between 5-10 years. Availability of data in the latter age group is limited globally [22] and but the available data reports iron supplementation is helpful in improving learning and memory [23-24]. Very few studies [25-26] have documented the effect of iron on cognitive functions in India. Thus, we conducted this study in children aged 5-10 years, belonging to rural area where awareness regarding nutrition is low, to study the extent of iron deficiency anemia and its impact on selected tests of cognitive function. We also evaluated the effect of iron supplementation on cognitive function in these children.

\section{Materials and Methods}

This study was conducted by the Department of Paediatrics at the Deccan college of Medical Sciences, Owaisi Teaching Hospital and Research Centre at Hyderabad, India. We conducted this study after obtaining approval from the Institutional ethics committee. Written informed consent was taken from the parent of the prospective patients prior to screening. We screened children of age group 5-10 yrs studying in a Government Primary school in a rural area of Hyderabad. Demographic data, medical history were recorded and relevant clinical examination was performed. Blood investigations for anemia included Haemoglobin ( $\mathrm{Hb}$, measured as gm /dl), Mean corpuscular volume (MCV) peripheral smear \& total iron binding capacity (TIBC) at baseline to categorize them into groups; Haemoglobin was repeated at the end of the study to note the change in the levels. Children were considered anemic if Haemoglobin levels were < $12 \mathrm{gms} / \mathrm{dL}$ [27].
Patients were grouped as follows:

Group-I Overt Anemia: $\mathrm{Hb}<12 \mathrm{mg} / \mathrm{dl}$ or MCV < 80fl

or Peripheral smear-showing microcyte or Hypochromic RBCs \& TIBC more than $400 \mu \mathrm{g} / \mathrm{dl}$.

- Group I A- who received iron supplement

- Group I B - without iron supplement

Group-II Latent Anemia: Hb> 12 gm/dl, MCV > 80fl. Peripheral smear - Normal, but TIBC $>400 \mu \mathrm{g} / \mathrm{dl}$.

- Group II A- who received iron supplement

- Group II B - without iron supplement

Group-III Non Anemics: Hb> 12 gm/dl, MCV > 80fl. Peripheral smear- normal \& TIBC $<400 \mu \mathrm{g} / \mathrm{dl}$

Base line cognitive function tests were performed in all the students using visual recall(PGI memory), clerical task for discrimination and perception capacity (NIMHANS-Specific learning disability index), Digit Span test for attention, short term auditory memory and sequencing (Dr.C.M.Bhatia's performance tests of Intelligence) [28]. Haemoglobin levels were estimated using Cyanmethemoglobin method, TIBC by Ferrozine method. Other laboratory tests were done as per the routine laboratory practice. Students who belonged to Group IA and Group II A were initially given a broad spectrum ant helmintic drug (Albendazole 400mg stat) under supervision by medical staff and then Iron supplementation with ferrous sulphate tablets $(60 \mathrm{mg}$ elemental iron) daily on all school working days for a period of 3 months. Compliance was ensured as the daily administration was done by the parents as recorded by the parents. At the end of 3 months of iron supplementation Haemoglobin and Cognitive function tests were repeated for the participants (193) and compared with the base line levels and cognitive function test scores.

StatisticalAnalysis- Data was captured using Microsoft Excel (2007) worksheets, analyzed with statistical software Stata 13 and expressed as frequency, percentages (categorical variables), mean and standard deviation (SD), median and ranges.Resultdescribed descriptively using tables and figures. The paired t test and unpaired $t$ test was used as applicable.

\section{Results}

Total study period was three months, of which total number of working days was 78 . We enrolled 193 children of whom 115 (59.59) were boys; mean $( \pm \mathrm{SD})$ age of participants was $7.87 \pm 1.42$ minimum of 06 years maximum of 10 yrs and median age was 08 years. Table 1 shows the demographic distribution among the study population.Of 193 children, Iron 
deficiency was seen in $119(61.65 \%)$, those with overt deficiency were 70 (36.27\%) and with latent deficiency were 49 $(25.39 \%)$.

Table-1: Demographic distribution among study population.

\begin{tabular}{|c|c|c|c|c|c|c|}
\hline \multirow[t]{2}{*}{ Group } & \multirow[t]{2}{*}{$\mathrm{n}$} & \multirow{2}{*}{$\begin{array}{l}\text { Boys } \\
\text { n (\%) }\end{array}$} & \multirow{2}{*}{$\begin{array}{l}\text { Girls } \\
\text { n }(\%)\end{array}$} & \multicolumn{3}{|l|}{ Age } \\
\hline & & & & Mean & SD & Range \\
\hline I & 71 & 39 & 32 & 7.87 & 1.4435 & $5-10$ \\
\hline A & $\begin{array}{l}35 \\
(49.29 \%)\end{array}$ & $19(54.28)$ & 16 & 7.77 & 1.41 & $5-10$ \\
\hline B & $\begin{array}{c}36 \\
(50.7 \%)\end{array}$ & $20(55.56)$ & 16 & 7.81 & 1.44 & \\
\hline II & 48 & 30 & 18 & 7.87 & 1.438 & $5-10$ \\
\hline A & $\begin{array}{l}23 \\
(47.9 \%)\end{array}$ & $15(65.25)$ & 08 & 7.82 & 1.43 & $5-10$ \\
\hline B & $\begin{array}{l}25 \\
(52.1 \%)\end{array}$ & $15(60 \%)$ & 10 & 7.79 & 1.41 & \\
\hline III & 74 & 46 & 28 & 7.85 & 1.40 & $5-10$ \\
\hline
\end{tabular}

Table 2 tabulates the baseline values Haemoglobin, MCV, TIBC among study population. Mean \pm SD Haemoglobin at baseline was $11.80 \pm 1.71 \mathrm{gm} / \mathrm{dL}$, MCV $82.07 \pm 4.69$ femolitres, TIBC was $403.58 \pm 58.77 \mu \mathrm{g} / \mathrm{dL}$.

Table2: Haemoglobin, MCV, TIBCamong study population at baseline.

\begin{tabular}{|c|c|c|c|c|c|c|c|}
\hline \multirow[b]{2}{*}{ Group } & \multirow[b]{2}{*}{$\mathbf{n}$} & \multicolumn{2}{|c|}{ Hb in $\mathrm{gm} / \mathrm{dL}$} & \multicolumn{2}{|l|}{ MCV } & \multicolumn{2}{|l|}{ TIBC } \\
\hline & & $\begin{array}{l}\text { Mean } \\
\text { (SD) }\end{array}$ & Range & Mean (SD) & Range & $\begin{array}{l}\text { Mean } \\
\text { (SD) }\end{array}$ & Range \\
\hline $\begin{array}{l}\text { I } \\
\text { Boys } \\
\text { Girls }\end{array}$ & $\begin{array}{l}71 \\
39 \\
32\end{array}$ & $9.71(1.39)$ & $7-11.4$ & $\begin{array}{l}77.71 \\
(4.61)\end{array}$ & $66-84.4$ & $\begin{array}{l}459.02 \\
(41.61)\end{array}$ & 416.2-578.1 \\
\hline $\begin{array}{l}\text { IA } \\
\text { IB }\end{array}$ & $\begin{array}{l}35 \\
36\end{array}$ & $\begin{array}{l}9.71(1.39) \\
10.23 \\
(1.13)\end{array}$ & $\begin{array}{l}7-11.4 \\
7.6-11.4\end{array}$ & $\begin{array}{l}76.78 \\
(4.84) \\
78.61 \\
(4.25) \\
\end{array}$ & $\begin{array}{l}66-84.1 \\
68-84.4\end{array}$ & $\begin{array}{l}468.44 \\
(45.21) \\
449.86 \\
(36.11)\end{array}$ & $\begin{array}{l}419.72- \\
578.1 \\
416.2-556.4\end{array}$ \\
\hline $\begin{array}{l}\text { II } \\
\text { Boys } \\
\text { Girls }\end{array}$ & $\begin{array}{l}48 \\
30 \\
18\end{array}$ & $\begin{array}{l}12.33 \\
(0.19)\end{array}$ & $12-12.9$ & $83.62(1.96)$ & $80.2-88.9$ & $\begin{array}{l}412.89 \\
(7.29)\end{array}$ & 401.7-426.7 \\
\hline $\begin{array}{l}\text { II A } \\
\text { II B }\end{array}$ & $\begin{array}{l}23 \\
25\end{array}$ & $\begin{array}{l}12.20 \\
(0.15) \\
12.26 \\
(0.22)\end{array}$ & $\begin{array}{l}12-12.5 \\
12-12.9\end{array}$ & $\begin{array}{l}83.79(2.08) \\
83.45(1.87)\end{array}$ & $\begin{array}{l}81.2-88.9 \\
80.2-87.5\end{array}$ & $\begin{array}{l}410.32 \\
(7.25) \\
415.26 \\
(6.62)\end{array}$ & $\begin{array}{l}401.7-426.7 \\
401.9-426.4\end{array}$ \\
\hline $\begin{array}{l}\text { III } \\
\text { Boys } \\
\text { Girls }\end{array}$ & $\begin{array}{l}74 \\
46 \\
28\end{array}$ & $\begin{array}{l}13.26 \\
(0.772)\end{array}$ & $12.2-15.8$ & $\begin{array}{l}85.24 \\
(2.19)\end{array}$ & $80.4-90$ & $\begin{array}{l}343.03 \\
(27.68)\end{array}$ & 257.4-388.4 \\
\hline
\end{tabular}

At baseline, mean \pm SD scores of visual recall, digit span and clerical test was $5.63 \pm 1.08,4.03 \pm 1.0$, and 7.16 \pm 1.39 respectively.

On comparison of baseline scores it was observed that students belonging to group III scored significantly better on all the three tests of cognitive functions. When compared to group I, the group II children scored better in digit span and clerical task test. But only clerical task test scores were significantly different (Table 3). Statistically significant difference was seen in Haemoglobin $(\mathrm{p}=0.001)$ and clerical task $(0.003)$ when group I was compared to Group II. 
Statistically significant difference $(\mathrm{p}<0.005)$ was seen in Haemoglobin levels and cognitive functions when Group I and II were compared to Group III, individually (Table 4).

Table 3: Comparison of Haemoglobin and cognitive tests -Baseline.

\begin{tabular}{|l|l|l|l|l|l|l|l|l|l|}
\hline Group & $\mathbf{n}$ & \multicolumn{2}{|l|}{ Hb in gm/dL } & \multicolumn{2}{l|}{ Visual recall } & \multicolumn{2}{l|}{ Digit span } & \multicolumn{2}{l|}{ Clerical Task } \\
\cline { 3 - 9 } & & $\begin{array}{l}\text { Mean } \\
(\text { SD) }\end{array}$ & Range & $\begin{array}{l}\text { Mean } \\
\text { (SD) }\end{array}$ & Range & $\begin{array}{l}\text { Mean } \\
(\text { SD) }\end{array}$ & Range & $\begin{array}{l}\text { Mean } \\
\text { (SD) }\end{array}$ & Range \\
\hline I & 71 & 9.974 & $7-11.4$ & 5.42 & $3-8$ & 3.69 & $2-7$ & 6.448 & $4.16-$ \\
& & $(1.284)$ & & $(1.097)$ & & $(0.994)$ & & $(1.285)$ & 8.88 \\
\hline II & 48 & 12.233 & $12-12.9$ & 5.125 & $3.5-8$ & 3.85 & $3-7$ & 7.165 & $5.2-9.2$ \\
& & $(0.189)$ & & $(1.024)$ & & $(0.989)$ & & $(1.252)$ & \\
\hline III & 74 & 13.26 & $12.2-15.8$ & 6.155 & $4.5-8$ & 4.472 & $3-7$ & 7.875 & $4.7-9.6$ \\
& & $(0.772)$ & & $(0.867)$ & & $(0.864)$ & & $(1.192)$ & \\
\hline
\end{tabular}

Table 4: Comparison of Haemoglobin and cognitive functions between groups at baseline.

\begin{tabular}{|l|l|l|l|l|}
\hline Group & Hb in gm/dl & Visual recall & Digit span & Clerical task \\
\hline I vs II & $0.001^{* *}$ & 0.221 & 0.501 & $0.003^{*}$ \\
\hline I vs III & $0.001^{* *}$ & $0.003^{*}$ & $0.001^{* *}$ & $0.001^{* *}$ \\
\hline II vs III & $0.001^{* *}$ & $0.001^{* *}$ & $0.001^{* *}$ & $0.002^{*}$ \\
\hline
\end{tabular}

Deworming under supervision was done to children who received iron supplements. Iron supplements were administered for 3 months to 58 students. Treatment compliance was $96.0 \%$.

After 3 months of iron supplementation, $52.86 \%$ (37/70) children still had haemoglobin $<12 \mathrm{gms} / \mathrm{d}$, while $80.83 \%$ $(156 / 193) \mathrm{had}<12 \mathrm{gms} / \mathrm{dL}$ (Table 5).

Table-5: Number of children categorized based on Haemoglobin level.

\begin{tabular}{|c|c|c|c|}
\hline \multirow[b]{2}{*}{ Hb at baseline } & \multicolumn{2}{|c|}{ Hb After iron supplement } & \multirow[t]{2}{*}{ Total } \\
\hline & $<12 \mathrm{gms} / \mathrm{dL}$ & $>12 \mathrm{gms} / \mathrm{dL}$ & \\
\hline$<12 \mathrm{gms} / \mathrm{dL}$ & 36 & 34 & 70 \\
\hline$>12 \mathrm{gms} / \mathrm{dL}$ & 1 & 122 & 123 \\
\hline Total & 37 & 156 & 193 \\
\hline
\end{tabular}

After 3 months of iron supplementation (iron supplementation given to group 1A AND 2A) Haemoglobin level and cognitive function test were repeated. Mean \pm SD Haemoglobin was $12.76 \pm 1.39 \mathrm{gm} / \mathrm{dL}$ at the end of the study; mean $( \pm \mathrm{SD})$ scores of visual recall, digit span and clerical task were $6.34 \pm 0.82,4.35 \pm 0.78$ And $7.98 \pm 1.19$ respectively. When compared, $\mathrm{Hb}$ values of group II and group III were significantly higher than group I. Group II scored better than group II in both visual recall test and clerical task test (Table 6). In all tests, group III scored better than group I. There was no significant difference in all tests between group I and group II (Table 7).

Table-6: Comparison of Haemoglobin and cognitive functions between groups after 3 months.

\begin{tabular}{|l|l|l|l|l|}
\hline Group & Hb in $\mathbf{g m} / \mathbf{d l}$ & Visual recall & Digit span & Clerical task \\
\hline I vs II & $0.001^{* *}$ & 0.500 & 0.396 & 0.064 \\
\hline I vs III & $0.001^{* *}$ & $0.014^{*}$ & $0.001^{* *}$ & $0.001^{* *}$ \\
\hline II vs III & 0.949 & $0.007^{*}$ & 0.053 & $0.041^{*}$ \\
\hline
\end{tabular}

When Haemoglobin was $>12$, mean scores were comparatively higher than those with Haemoglobin $<12$ gms/dL (Table 8). 
Table-7: Cross table comparing mean Haemoglobin levels and mean cognitive tests at baseline and after iron supplementation

\begin{tabular}{|c|c|c|c|c|c|c|c|c|c|c|c|c|}
\hline$\underset{\downarrow}{\text { After }} \rightarrow$ & $\begin{array}{l}\text { Visu } \\
\text { base }\end{array}$ & recall & $\begin{array}{l}\text { Visual } \\
\text { after } \\
\text { supple }\end{array}$ & $\begin{array}{l}\text { recall } \\
\text { iron } \\
\text { ent }\end{array}$ & $\begin{array}{l}\text { Digit } \\
\text { Baseli }\end{array}$ & span. & $\begin{array}{l}\text { Digit } \\
\text { after } \\
\text { suppl }\end{array}$ & $\begin{array}{l}\text { span } \\
\text { iron } \\
\text { ent }\end{array}$ & $\begin{array}{l}\text { Cler } \\
\text { Bas }\end{array}$ & li task. & $\begin{array}{l}\text { Cle } \\
\text { afte } \\
\text { sup }\end{array}$ & $\begin{array}{l}\text { lask } \\
\text { iron } \\
\text { ment }\end{array}$ \\
\hline $\begin{array}{l}\text { Base } \\
\text { line }\end{array}$ & $\begin{array}{l}\text { Cat } \\
\text { A }\end{array}$ & Cat B & Cat A & $\begin{array}{l}\text { Cat } \\
\text { B }\end{array}$ & Cat A & $\begin{array}{l}\text { Cat } \\
\text { B }\end{array}$ & Cat A & $\begin{array}{l}\text { Cat } \\
\text { B }\end{array}$ & $\begin{array}{l}\text { Cat } \\
\text { A }\end{array}$ & $\begin{array}{l}\text { Cat } \\
\text { B }\end{array}$ & $\begin{array}{l}\text { Cat } \\
\text { A }\end{array}$ & $\begin{array}{l}\text { Cat } \\
\text { B }\end{array}$ \\
\hline $\begin{array}{l}\text { Category } \\
A^{*}\end{array}$ & 5.3 & 5.45 & 5.98 & 6.48 & 3.61 & 3.7 & 3.97 & 4.47 & 6.3 & 6.47 & 7.3 & 7.78 \\
\hline $\begin{array}{l}\text { Category } \\
\mathrm{B} \dagger\end{array}$ & 5.5 & 5.76 & 6.5 & 6.4 & 4 & 4.24 & 4 & 4.42 & 8 & 7.6 & 8.8 & 8.23 \\
\hline
\end{tabular}

*Category A - Haemoglobin< $12 \mathrm{gms} / \mathrm{dL}$ and $\dagger$ category B - Haemoglobin $>12 \mathrm{gms} / \mathrm{dL}$.

There was no statistically significant difference in cognitive functions between boys and girls among groups and subgroups at baseline and after 3 months.

Subgroup analysis- There was no statistically significant difference between group IA \& IB before iron supplementation. figure 1 depicts the Haemoglobin and mean scores of cognitive tests at baseline and figure 2 after supplementation. But after 3 months of iron supplementation group IA scored better in all the test items than group IB.Before iron supplementation, group IIB scored in all cognitive function tests significantly better than group IIA. But after iron supplementation given to group IIA they scored better in all the tests than group IIB. Before iron supplementation, group IA scored better than group IIA in visual recall test. But after iron supplements there was no significant difference noticed in all the test items.

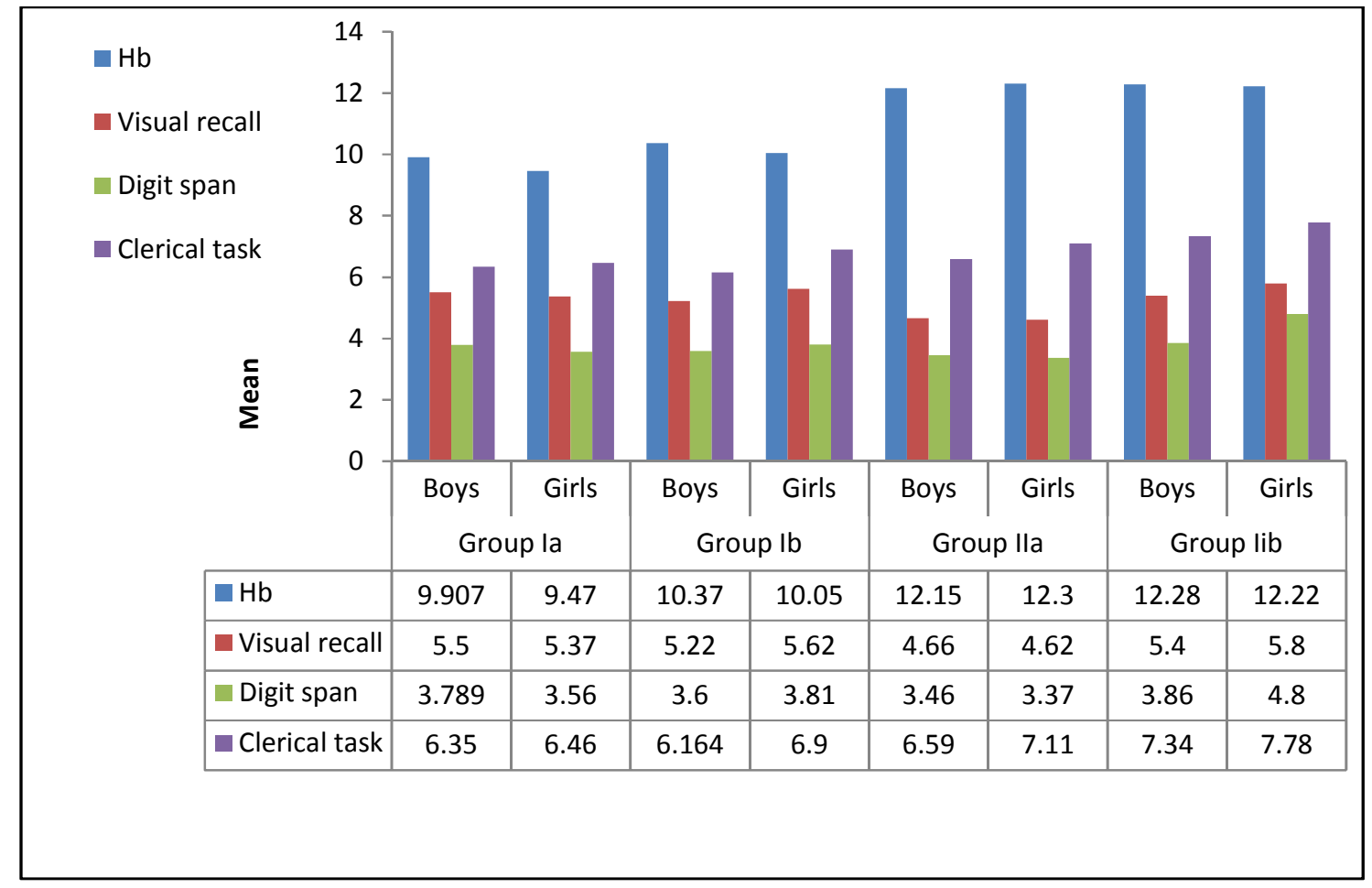

Figure-1: Comparison of Haemoglobin and cognitive functions among anemic boys and girls at baseline. 


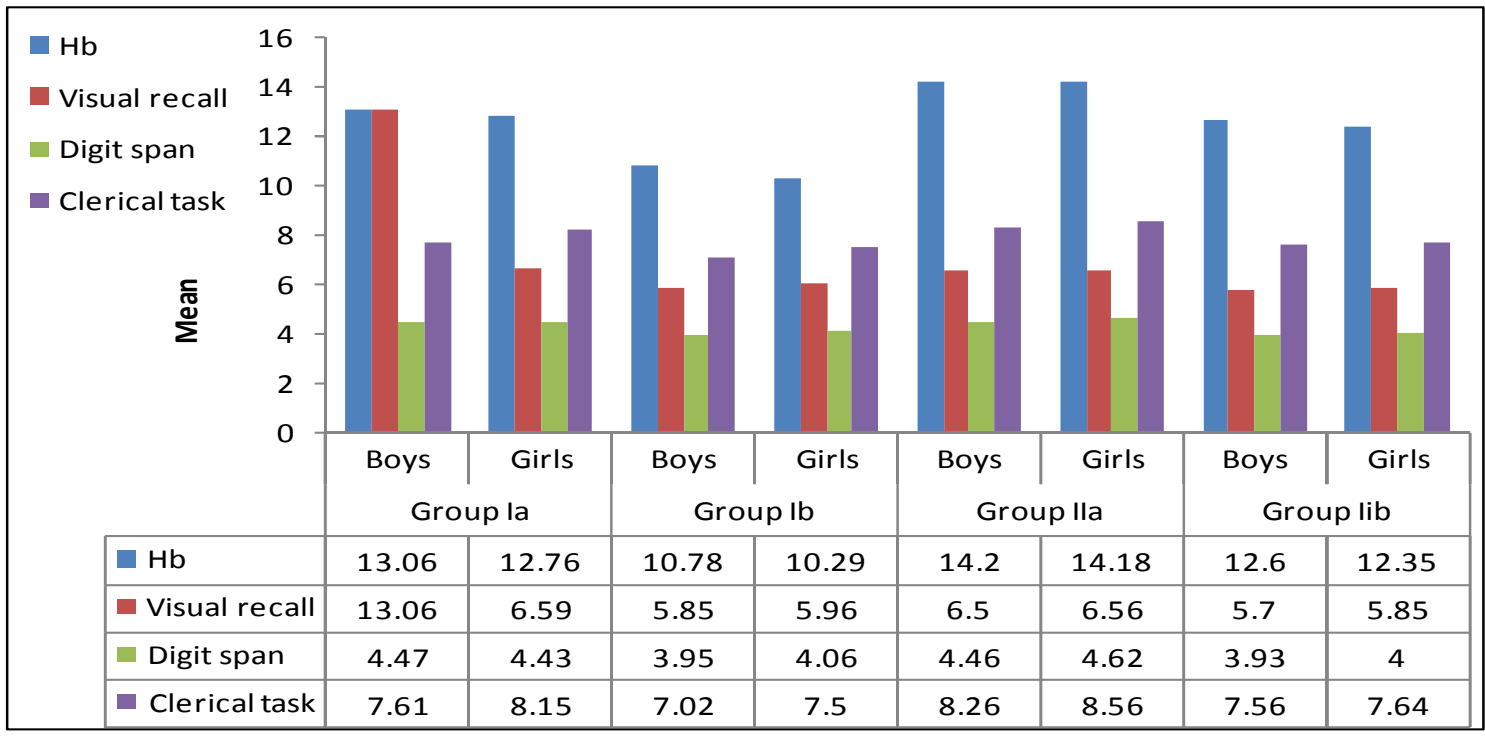

Figure 2: Comparison of Haemoglobin and cognitive functions among anemic boys and girls after 3 months.

There was no untoward effect was reported by the study participants.

\section{Discussion}

Nutritional deficiencies are major concern in pediatric practice. Though it is a global trend, prevalence is more among developing and underdeveloped South Asian countries $[4,27,29]$ though showing some declining trend due to enforcement of anemia surveillance programs and supplementation [30]. Deficiency of micronutrients including that of iron and its relationship to cognitive and physical functions in childhood in Indian children has been reviewed by Swaminathan $\mathrm{S}$ et al [31].

Of all the nutritional deficiencies, Iron deficiencyis the most common clinical entity. Its relationship to neural development [32], development of neuropsychological domains [33], cognitive functions, behavioral, overall growth and development of the child has been recognized [34-37]. Falkingham $M$ et al [13] though reported positive association in children $>6$ years but stated the requirement of further studies. However, there are reports of negative association between iron deficiency and cognitive development [38] indicating requirement of further research in this therapeutic area.

Most of the studies have been done during early childhood; few studies have been done in 5-10 years age group which have documented lower cognitive functions and strongly recommended iron supplements to improve the declining cognitive functions [39]. Studies have shown neural development continues beyond infancy and that of higher order cognitive functions continue still further till adulthood [40]. Thus intervention in this stage is expected to limit the progress and improve the perturbed cognitive functions. Most of the studies on Iron deficiency have been conducted in urban parts of India [31]. We included children from rural part of Hyderabad, India, where most of the population were just above the poverty line and belonged to lower middle class group. The major source income of the population comes through Agriculture and labor. We screened children studying in a Government primary school whose diet at home is nutritionally deficient. These children are recipients of mid day meal program offered by the Government which comprises $25 \%$ of recommended dietary intake.Previous studies have recorded that iron deficiency anemia is more prevalent in lower socioeconomic group [41]. Though our study is supportive of this, we cannot conclude as we did not include children from upper middle and higher socioeconomic class of our society. Anemia was recorded in $61.65 \%$ of study population indicating the severity of the underlying problem. This does not depict the entire pediatric population of that area; it is just the tip of the iceberg directing the requirement of more research in this field.

Evidences relate worm infestation to lower cognitive functions [42-45] studies have shown better rate of improvement with deworming and iron supplements [46]. Deworming before iron supplementation is 
routinely followed in clinical practice; thus, we dewormed only the participants who received iron supplements before initiating.

After iron supplements, there was an increase in Haemoglobin levels; 80.83\% (156/193) had < 12 gms/dLwhile $52.86 \%$ (37/70) children still had haemoglobin<12gms/dL. We observed that with increase in Haemoglobin had positive association to the cognition, confirming lower cognitive functions in anemic children compared to non anemic, and we did not find any gender difference.Among the anemic children statistically significant $(\mathrm{p}=0.003)$ difference was noted only in clerical task, without any difference in memory and visual recall between overt and latent anemic children. An interesting observation was girls in group II (A) had significantly higher mean Haemoglobin as compared to boys and group II (B) girls scored better in Digit Span. All the other differences between the boys and girls were not significant. Deworming was done for all children to rule out the possibility of worm infestation as one of the cause for anemia considering their social background. Iron supplements were administered for three months (on working day) and we observed good therapeutic compliance of $96 \%$. Oral supplement was well tolerated by our study population.

After supplementation, there was increase in Haemoglobin in all children as expected. Improvement in test scores was similar to baseline with better performance by those in group III. Among the groups, there was statistically significant (p <0.005) improvement in those who received iron supplement compared to those who did not.

As early as in 1985, Gopaldas T et al [47] observed anaemic children scored better than the non-anaemics with respect to digit span, while in other two tests nonanaemics faired better, highlighting the impact of iron deficiency in school children, a problem which was considered oblivious in this population. They noted a statistically significant improvement in visual recall, digit span, and clerical task test after iron supplementation for 90 days at either dose $(30 \mathrm{mg}$ and $40 \mathrm{mg}$ of elemental $\mathrm{Fe}$ ) in school children with haemoglobin $</=10.5 \mathrm{gm} / \mathrm{dL}$. In contrast, our study noted better performance by non-anaemic children than their anaemic counterparts in all three tests, but support the latter fact. Later, in 1989, Seshadri S et al[26], discussed four studies, conducted in 5-15 years which showed improvements in cognitive functions varying from varying levels of improvement, clear beneficial effects to significantly improved scores.

Iron supplements have shown positive results in terms of improved cognition in anemic in adolescent Indian girls[48], and our results are supportive of this. This study was done in children from Government primary schools, similar to ours.

Global studies too have inked the positive association between iron deficiency and cognition. Falkinghamet al[13] in their meta-analysis of the 14 studies, observed improvement in intelligent quotient in anemic children with iron supplementation. Cross-sectional study in Combodian school children $>5$ years proved the inter relationship between iron deficiency and decline in cognitive functions. In this study, unlike our study, iron deplete boys fared lower than their counterparts (girls). This study showed even low levels of iron, in the absence of anemia can result in lower cognitive functions [24].

Short duration of study and small study population bars us from drawing concrete conclusion. Minimal laboratory investigations were done due to cost factor. Serum ferritin levels would have better indicators, but was not done as it was expensive. We did not correlate socioeconomic background and strata, diet,parental awareness, physiological changes, coexisting illnesses which would have contributed to iron deficiency and anthropometric measurements to anemia which would have been useful information. Correlation with academic grades would have confirmed our finding. We administered oral formulations of iron supplements. Though we did not measure academic performance of these children, improvement in cognitive functions indirectly help to perform better.

Considering the age group, improvised palatable formulations would have been more acceptable. Though there have been reports of unpleasant experiences with oral formulation such as hard and dark coloured stool, abdominal symptoms, none of our participant complained this. This could be due to prior information provided.

Our study strengthens the hypothesis that iron deficiency anaemia leads to diminished cognitive functions and iron supplementation improves cognitive functions, supporting the national Iron plus initiative for anaemia control program. However, at the backdrop of contradictory results on the improvement of cognitive 
functions in children from various studies, we need more randomized trials to arrive at a definite conclusion. We emphasize on regular deworming, and supplement therapy especially in the children of primary school for their future success. In addition, parental awareness about balanced diet, nutrition, medical care would add to strengthen the existing programmes.

\section{Conclusion}

Non anemic children perform better than those with anemia; performance of those with latent anemia is better than those with overt anemia. Iron supplementation helps in improved performance in these children.

Acknowledgement- We acknowledge all children who participated in this study. We thank the Head master and teachers who allowed us to conduct this study in their school. We acknowledge the support of Dept of Health education who granted no objection for this study. We thank the staff, and management of the Deccan college of Medical Sciences, Owaisi Teaching Hospital and Research Centre at Hyderabad, India for their support. We thank DrLatha for the assistance in the preparation, editing of this manuscript.

\section{Funding: Nil, Conflict of interest: Nil \\ Permission from IRB: Yes}

\section{References}

1. Lozoff B, Brittenham GM. Behavioral alterations in iron deficiency. HematolOncolClin North Am. 1987 Sep;1(3):449-64.

2. Dallman PR. Iron deficiency: does it matter? J Intern Med. 1989 Nov;226(5):367-72.

3. Jauregui-Lobera I: Iron deficiency and cognitive functions. Neuropsychiatr Dis Treat. 2014 Nov 10;10: 2087-95. doi: 10.2147/NDT.S72491.eCollection 2014.

4. Detzel P, Wieser S. Food fortification for addressing iron deficiency in Filipino children: benefits and costeffectiveness. Ann NutrMetab. 2015;66Suppl 2:35-42. doi: $10.1159 / 000375144$.

5. Deinard AS, List A, Lindgren B, Hunt JV, Chang PN. Cognitive deficits in iron-deficient and irondeficient anemic children.J Pediatr. 1986 May;108(5 Pt 1):681-9.
6. Eden AN. Iron deficiency and impaired cognition in toddlers: an underestimated and undertreated problem. Paediatr Drugs. 2005;7(6):347-52.

7. Oski FA, Honig AS. The effects of therapy on the developmental scores of iron-deficient infants.J Pediatr. 1978 Jan;92(1):21-5.

8. Pollitt E, Hathirat P, Kotchabhakdi NJ, Missell L, Valyasevi A. Iron deficiency and educational achievement in Thailand. Am J ClinNutr. 1989 Sep;50 (3 Suppl):687-96; discussion 696-7.

9. Webb TE, Oski FA. Iron deficiency anemia and scholastic achievement in young adolescents. J Pediatr. 1973 May;82(5):827-30.

10. Pollitt E. Iron deficiency and educational deficiency. Nutr Rev. 1997 Apr;55(4):133-41.

11. Taras H. Nutrition and student performance at school. J Sch Health. 2005 Aug;75(6):199-213.

12. Hermoso M, Vucic V, Vollhardt C, Arsic A, Roman-Vinas B, et al. (2011) The Effect of Iron on Cognitive Development and Function in Infants, Children and Adolescents: A Systematic Review. Ann NutrMetab. 2011;59(2-4):154-65. doi: 10.1159/ 000334490 .

13. Falkingham $M$, Abdelhamid A, Curtis $P$, Fairweather-Tait S, Dye L, Hooper L. The effects of oral iron supplementation on cognition in older children and adults: a systematic review and meta-analysis. Nutr J. 2010 Jan 25;9:4. doi: 10.1186/1475-2891-9-4.

14. Tran TD, Biggs BA, Tran T, Simpson JA, Hanieh S, Dwyer $\mathrm{T}$ et al. Impact on Infants' Cognitive Development of Antenatal Exposure to Iron Deficiency Disorder and Common Mental Disorders. PLoS One. 2013 Sep 23;8(9):e74876. doi: 10.1371/journal. pone.0074876. eCollection 2013.

15. Algarín C, Nelson CA, Peirano P, Westerlund A, Reyes S, Lozoff B. Iron-deficiency anemia in infancy and poorer cognitive inhibitory control at age 10 years. Dev Med Child Neurol. 2013 May;55(5):453-8. doi: 10.1111/dmen.12118.

16. Fuglestad AJ, Georgieff MK, Iverson SL, Miller BS, Petryk A, Johnson DE et al. Iron deficiency after arrival is associated with general cognitive and 
behavioral impairment in post-institutionalized children adopted from Eastern Europe.Matern Child Health J. 2013 Aug;17(6):1080-7. doi: 10.1007/s10995-0121090-z.

17. Matiashvili K, Manjavidze $\mathrm{N}$, Ghonghadze $\mathrm{T}$. Influence of ferrotherapy on psychomotor development of children of yearly age with iron deficiency anemia. Georgian Med News. 2012 May;(206):38-41.

18. Lozoff B, Jimenez E, Smith JB. Double burden of iron deficiency in infancy and low socioeconomic status: a longitudinal analysis of cognitive test scores to age 19 years. Arch PediatrAdolesc Med. 2006 Nov;160(11):1108-13.

19. Metallinos-Katsaras E, Valassi-Adam E, Dewey KG, Lönnerdal B, Stamoulakatou A, Pollitt E. Effect of iron supplementation on cognition in Greek preschoolers. Eur J ClinNutr. 2004 Nov;58(11):153242.

20. Soewondo S. The effect of iron deficiency and mental stimulation on Indonesian children's cognitive performance and development.Kobe J Med Sci. 1995 Apr;41(1-2):1-17.

21. Soewondo S, Husaini M, Pollitt E. Effects of iron deficiency on attention and learning processes in preschool children: Bandung, Indonesia. Am J ClinNutr. 1989 Sep;50(3 Suppl):667-73; discussion 673-4.

22. Best C, Neufingerl N, van Geel L, van den Briel T, Osendarp S. The nutritional status of school-aged children: why should we care? Food Nutr Bull. 2010 Sep;31(3):400-17.

23. Baumgartner J, Smuts CM, Malan L, Kvalsvig J, van Stuijvenberg ME, Hurrell RF et al. Effects of iron and n-3 fatty acid supplementation, alone and in combination, on cognition in school children: a randomized, double-blind, placebo-controlled intervention in South Africa. Am J ClinNutr. 2012 Dec;96(6):1327-38. doi: 10.3945/ajcn.112.041004

24. Perignon $M$, Fiorentino $M$, Kuong $K$, et al. Stunting, Poor Iron Status and Parasite Infection Are Significant Risk Factors for Lower Cognitive Performance in Cambodian School-Aged Children. Sengupta S, ed. PLoS ONE. 2014;9(11):e112605. doi:10.1371/journal.pone.0112605.
25. Sachdev H, Gera T, Nestel P. Effect of iron supplementation on mental and motor development in children: systematic review of randomised controlled trials. Public Health Nutr. 2005 Apr;8(2):117-32.

26. Seshadri S, Gopaldas T. Impact of iron supplementation on cognitive functions in preschool and school-aged children: the Indian experience. Am J ClinNutr. 1989 Sep;50(3 Suppl):675-84; discussion 685-6.

27. DeMaeyer EM, Dallman P, Michael GJ, Hallberg L, Sood SK, Srikantia S G, World Health Organization. Preventing and Controlling Iron Deficiency Anemia Through Primary Health Care. Geneva, World Health Organization, 1989. Available from http://www.who. int/iris/handle/10665/39849\#sthash.QAdApF1Q.dpuf last accessed 5 June 2016.

28. Dutt A. Cognitive Screening Tools \& Neuropsychological Tests in India. A list.Available from http:// www.wfnteachoogn.in / downloads/ Cognitive\%20Tests\%20and\%20Screening\%20Tools_In dia.pdf Accessed on 20 May 2016.

29. Black RE, Victora CG, Walker SP, Bhutta ZA, Christian $\mathrm{P}$, de Onis $\mathrm{M}$, et al. Maternal and child undernutrition and overweight in low-income and middle-income countries. Lancet. 2013 Aug 3;382(9890):427-51. doi: 10.1016/S0140-6736(13) 60937-X

30. Sungthong R, Mo-suwan L, Chongsuvivatwong V, Geater AF. Once-weekly and 5-days a week iron supplementation differentially affect cognitive function but not school performance in Thai children. J Nutr. 2004 Sep;134(9):2349-54.

31. Swaminathan S, Edward BS, Kurpad AV. Micronutrient deficiency and cognitive and physical performance in Indian children. Eur J ClinNutr. 2013 May;67(5):467-74. doi: 10.1038/ejcn.2013.14.

32. Walter T. Effect of iron-deficiency anemia on cognitive skills and neuromaturation in infancy and childhood.Food Nutr Bull. 2003 Dec;24(4 Suppl):S10410.

33. Beltrán-Navarro B, Matute E, Vásquez-Garibay E, Zarabozo D. Effect of chronic iron deficiency on neuropsychological domains in infants. J Child Neurol. 
2012 Mar;27(3):297-303. doi: 10.1177/ 0883073 811416867 .

34. Madan N, Rusia U, Sikka M, Sharma S, Shankar N. Developmental and neurophysiologic deficits in iron deficiency in children. Indian J Pediatr. 2011 Jan;78(1):58-64. doi: 10.1007/s12098-010-0192-0.

35. Monga M, Walia V, Gandhi A, Chandra J, Sharma S. Effect of iron deficiency anemia on visual evoked potential of growing children. Brain Dev. 2010 Mar;32(3):213-6. doi: 10.1016/j.braindev.2009.02.009.

36. Ayala R, Otero GA, Porcayo Mercado R, PliegoRivero FB. Delayed CNS maturation in iron-deficient anaemic infants.NutrNeurosci. 2008 Apr;11(2):61-8. doi: 10.1179/147683008X301342.

37. Lozoff B. Iron deficiency and child development. Food Nutr Bull. 2007 Dec;28(4 Suppl):S560-71.

38. Glazer Y, Bilenko N. Effect of iron deficiency and iron deficiency anemia in the first two years of life on cognitive and mental development during childhood. Harefuah. 2010 May;149(5):309-14, 335. [Article in Hebrew].

39. Agaoglu L, Torun O, Unuvar E, Sefil Y, Demir D. Effects of iron deficiency anemia on cognitive function in children. Arzneimittelforschung. 2007;57(6A):42630.

40. Bryan J1, Osendarp S, Hughes D, Calvaresi E, Baghurst K, van Klinken JW. Nutrients for cognitive development in school-aged children.Nutr Rev. 2004 Aug;62(8):295-306.

41. Baumgartner J, Barth-Jaeggi T. Iron interventions in children from low-income and middle-income populations: benefits and risks. CurrOpinClin NutrMetab Care. 2015 May;18(3):289-94. doi: 10.1097/MCO.0000000000000168.
42. Nokes C, Grantham-McGregor SM, Sawyer AW, Cooper ES, Bundy DAP. Parasitic helminth infection and cognitive function in school children.Proceedings of the Royal Society of London. Series B: Biological Sciences. 1992;247: 77-81.

43. Sakti H, Nokes C, SubagioHertanto W, Hendratno S, Hall A, Bundy DA et al. Evidence for an association between hookworm infection and cognitive function in Indonesian school children. Tropical Medicine \& International Health.1999; 4: 322-334. doi: 10.1046/j. 1365-3156.1999.00410.x

44. Jardim-Botelho A., Raff S, DeÁvila Rodrigues R, Hoffman HJ, Diemert DJ, Corrêa-Oliveira R, et al. Hookworm, Ascarislumbricoides infection and polyparasitism associated with poor cognitive performance in Brazilian schoolchildren. Tropical Medicine \& International Health.2008;13:994-1004. doi: 10.1111/j.1365-3156.2008.02103.x

45. Partnership for Child Development. Heavy schistosomiasis associated with poor short-term memory and slower reaction times in Tanzanian schoolchildren. Tropical Medicine \& International Health.2002; 7: 104-117.doi: 10.1046/j.1365-3156. 2002.00843.x

46. Boivin MJ, Giordani B. Improvements in cognitive performance for schoolchildren in Zaire, Africa, following an iron supplement and treatment for intestinal parasites. J. Pediatr. Psychol. (1993) 18 (2): 249-264.doi: 10.1093/jpepsy/18.2.249

47. Gopaldas T, Kale M, Bharadwaj P. Prophylactic Iron supplementation for under privileged school boys. Impact on selected tests of cognitive functions.Indian Pediatr. 1985 Oct;22(10):737-43.

48. Sen A, Kanani SJ. Impact of iron-folic acid supplementation on cognitive abilities of school girls in Vadodara.Indian Pediatr. 2009 Feb;46(2):137-43.

\section{How to cite this article?}

Naseem A, Khan S. A., Lalani N. Impact of iron deficiency on cognitive functions and effect of iron supplement in children between 5-10 years: Indian perspective. Int J Pediatr Res 2016;3(5):313-322.doi:10.17511/ijpr.2016.i05.08 